\title{
Student Perceptions about Veterans Service in Fighting Indonesia's Independence at State Junior High School
}

\author{
Wingkolatin ${ }^{1}$, Jamil $^{2}$ \\ Faculty of Teacher Training and Education, Mulawarman University, Samarinda, East Kalimantan, Indonesia \\ winko.latin@yahoo.co.id, jamil_737sar@yahoo.com
}

\begin{abstract}
Problems that often occur in students lack of knowledge about veteran services so as to cause the soul of student nationalism becomes less so the purpose of this study is to know the students' perceptions about the services of veterans in fighting for independence of Indonesia in SMPN 2 Samarinda. This study used descriptive qualitative method. Focusing on students' perceptions about the services of veterans of Indonesian independence fighters and the meaning of values of veteran struggle against students in SMPN 2 Samarinda. With primary data source is student, teacher of Civics and principal of SMPN 2 Samarinda and secondary data in the form of documents. And in this research data collection technique used is observation, interview, and documentation. And the data analysis techniques include data collection, data reduction, data presentation and drawing conclusions. As for the results of research related to students' perceptions about the services of veterans in fighting for independence of Indonesia into the category is quite good, almost all students know and understand well who the independence fighters $R I$ in particular veterans, with different levels of knowledge and understanding of each student, some of them said that the veteran is a former freedom fighter RI who used to plunge into the battlefield against the invaders and now their task is complete. From the research results obtained then the importance of a teacher explain the veteran services to students by deepening the students' knowledge related to Indonesian warriors through Civics subjects.
\end{abstract}

Keywords-Perception, Veterans Service, Independence

\section{INTRODUCTION}

Independence is a freedom, which is free from all kinds of shackles, rules, and powers of certain parties. Independence is not just a slogan in life. Independence is a trace of the struggle of what a nation aspires to. The Indonesian Independence Proclamation read out on August 17, 1945 is the recognition of the Indonesian nation to the outside world or other countries that Indonesia has declared itself as an independent state. However, this freedom will not be realized without the struggle and sacrifice given by the sons and daughters of the Indonesian nation to achieve the independence. History proves that the independence of Indonesia is not a gift from the colonist but the result of the struggle of all Indonesian people are the fighters and defenders of independence of Indonesia, in this case those we know as veterans also have a role in reaching, defending and defending the independence. As a child of a nation now free from physical colonization in the past, we must give appreciation and appreciation to those who have been willing to sacrifice their wealth, soul, body and even family to achieve the independence we now feel.

Veterans of the Republic of Indonesia consists of two generations based on the period of armed struggle they experienced. The first generation were veterans who fought in the war of independence from 1945 to 1949 who were granted honorary status as veterans of freedom fighters. The second generation was the veterans who fought against the foreign forces after 1950 to defend the integrity of the state and nation, they were called veterans of independence defenders. The first group fighting against the Dutch in the Irian Jaya trikora operation in 1962 was called a trikora veteran. The second group in 1965 fought against the British was called a veteran dwikora. The last group was those who fought against the Portuguese in 1975 called the veteran seroja.

Being honored as a veteran does not guarantee a decent and sufficient life for them and not a few of them whose lives are hard and forgotten. Hero as a person who has a very big service for the struggle in maintaining the independence of the Republic of Indonesia should be a role model and example for each individual young generation, especially the fighting spirit of the heroes must remain attached to the younger generation, especially in filling independence.

The struggle is long overdue, as the veterans are no longer young, but they are eager to devote themselves to the state that is implemented through the Veterans Legion of the Republic of Indonesia (LVRI), the only veteran organization in Indonesia. LVRI is an organization inaugurated by President Soekarno, on January 2, 1957 with the issuance of Presidential Decree No. RI. 103 of 1957 . The organization then undertook various consolidations to bring together veterans of the Republic of Indonesia, which according to Law no. 7 of 1967 states that the state needs to reward those who have actively donated their labor on a voluntary basis in the union of both official and armed bonds to fight for, defend and defend the independence of the Unitary State of the Republic of Indonesia. Because a great nation is a nation that values the heroes. So said Bung Karno, Mr. Proclaimer and also the first President of RI.

Therefore, as a great nation should be its citizens to respect and appreciate the services of the heroes, especially the younger generation. To develop and shape the character and civilization of a dignified nation, it is necessary that intelligent 
young generation. Because the young generation, especially the students who are taking education both in primary and secondary schools is an important asset for a country. Because the young generation is the seeds that must be developed to become a generation that can advance religion, nusa and nation. A good learner should be able to put themselves well among the community. As a learner, indirect knowledge and skills are also better than others. And this requires that learners behave politely in order to be imitated by other societies who are uneducated or poorly educated. Because the progress of a nation and state is determined by the progress of the learners. Because the learned people are capable of bringing change to a nation and state. In addition, the existence of learners as a young generation is expected to be a good characteristic for the Indonesian nation and regeneration to continue and realize the ideals of the Indonesian nation that has long been championed by the predecessors in this country.

\section{METHOD RESEARCH}

The type of this research is descriptive research supported with the opinion of Sugiyono (2014) "qualitative research method is a research method used to examine the condition of natural objects, (as opposed to experiments) where researchers are as a key instrument, data collection techniques are done in triangulation (composite), data analysis is inductive, and qualitative research results emphasize the meaning of generalization".

\section{A. Data collection technique}

Data collection was done by interview and supported by questionnaire related to student perception about Veteran Service of Indonesian independence fighters. Where some indicators become benchmarks as follows:

- Student perceptions about the veteran services of Indonesian independence fighters, the indicators are:

a) Heroes in the period of physical revolution

b) Courage against the invaders during the period of physical revolution

c) Fight for the independence of Indonesia during the period of physical revolution

- The meaning of values of veteran struggle against students, the indicator is:
a) The value of patriotism
b) Unyielding value
c) The value of cooperation

\section{B. Data analysis technique}

Data analysis technique is done by collecting data from interviews, questionnaires, then data is reduced and draw conclusions according to assessment indicators. For more details can be seen in the picture below:

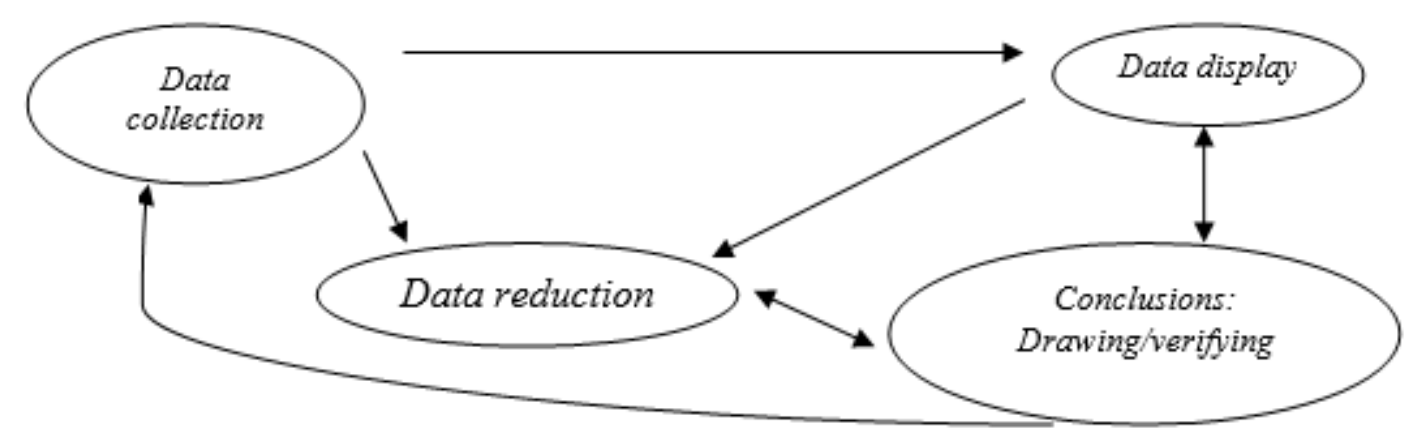

Fig. 1. Components of Data Analysis: Interactive Model

\section{RESEARCH FINDINGS AND DISCUSSION}

The independence of Indonesia proclaimed on August 17, 1945 read by Ir. Sukarno is a sacred statement stating that the Indonesian nation has been liberated from the colonialists and has become an independent nation, but it cannot be separated from the struggle of the Indonesian people to achieve independence. Before feeling the sweetness of independence that we now feel there must be a struggle made by the people of Indonesia to gain that independence and the struggle that they do is not an easy struggle but it is a hard struggle that is a struggle that sacrificed their time, energy, property, soul and even body. Therefore, as a young generation who has felt the beauty of freedom given by our heroes, we certainly should appreciate their services that are grateful for the favors of independence by filling the independence of Indonesia in accordance with their skills, expertise and skills. The Indonesian independence fighters are the people of Indonesia who are willing to sacrifice their soul and body to fight for and defend the independence of Indonesia including veterans who fought during the physical revolution. From the above explanation the author initiated a question relating to students' knowledge about who the freedom fighters of Indonesia and who is veteran.

According to SA class IX students: "The independence warrior of Indonesia depends on the time or time or at the time of reform or during the war, if at the time of the revolution of Soekarno, Soeharto, Sudirman. Whereas the veteran is a hero of antiquity who have retired ". (Based on the results of interview on May 11, 2015) 
Meanwhile, according to grade IX students with the initials A stated his opinion that: "Freedom fighters much like Sukarno, Moh. Hatta, Sultan Hasanuddin, if my veteran does not know who is a veteran ". (Based on interview result on May 11, 2015).

Another opinion expressed by the students of class IX with the initials QA which states that: "Freedom fighters RI is the heroes, teachers also include students in schools, officials who provide solutions for the progress of the Indonesian nation and heroes are veterans struggled in antiquity to seize independence ". (Based on interview result on May 11, 2015).

In addition, students of class VIII name is $\mathrm{NJ}$ also expressed his opinion that: "I think the freedom fighter RI is a person who fought for independence, the children of the nation as well as those who excel as well for the nation of Indonesia. While the veteran is a hero who fought in the past that is still alive ". (Based on interview result dated May 12, 2015)

Another opinion was also expressed by students of class VIII with initials IR stated that: "I think the freedom fighter RI like Pangeran Diponegoro and many more others and if the veterans are the soldiers who fought against the countries that colonized Indonesia". (Based on the results of interview on May 11, 2015)

A similar opinion was also expressed by students with the initials of MD which states that: "The freedom fighters of Indonesia are those who have fought for Indonesia to be free from colonialism, and the hero is not only those who fight physically alone against invaders but they are also struggling through political affairs such as Ir. Soekarno, Moh. Hatta may be called a hero as well, whereas if the veteran is a former Indonesian freedom fighter who fights invention country in war but now retired" (Based on interview result on May 11, 2015).

While students of class VII with initials MI states that: "Freedom fighters of Indonesia, among others $\mathrm{Ki}$ Hajar Dewantara, Ir. Soekarno, B.J Habibie, Soedirman and many more and if my veteran has never heard of veterans ". (Based on interview result on May 11, 2015).

Other opinions expressed by students of class VII initials RF also expressed his opinion by stating that: "Ir. Soekarno, Moh. Hatta, Ki Hajar Dewantara. Indonesian independence fighters are a very important figure for the Indonesian nation and $\mathrm{Ki}$ Hajar Dewantara is an educational figure for the Indonesian state. And the veteran is a former fighter fighting over the Indonesian nation in the past ". (Based on the results of interview on May 11, 2015)

Another opinion which is not much different was expressed by the students of class VII with initials YS stated that: "RI independence fighters like Ki Hajar Dewantara, Imam Bonjol, Diponegoro, Antasari. And I think the veteran is a position in the army". (Based on interview result on May 11, 2015). In addition the authors also want to know the opinion of principals and teachers subject to PPKn about who the veteran.

According to the headmaster of SMPN 2 with initials father M stated that: "Veterans are people who fought at that time seize independence as a soldier but not as an official soldier, that is, only those who struggled to achieve and maintain independence in 1945 so eventually called veterans". (Based on interview result dated May 13, 2015).

The opinion is not much different told by the subject teacher PPKn who father LA stated that: "If according to my perception veteran it's different with heroes, but if veterans are those who fight for the nation and the country, but they are not listed in the TNI for example. The veteran is a person who fights for the nation and the country but they do not expect anything from the government, because many veterans, who are veteran people who are fighting for the sake of the nation, anyone. But they are not servants to non-governmental countries, not government apparatus but the general public who are willing to fight for the benefit of the nation and state including the environmental veteran for me because he is fighting for the benefit of society but he is not a civil servant he is not a security apparatus. During the struggle, many were struggling with arms but they were not TNI, after they had finished their struggle, but if the TNI after they fought they were the leaders of the nation, some became employees, some became soldiers and so on. If veterans do not, veterans are people who work hard for the country but do not expect anything in return from the state ". (Based on interview result dated May 13, 2015).

Another opinion was also raised by a PPKn subject teacher with the initials of LN's mother stating that: "The veteran's understanding up until now is still ambiguous, whether those who struggle though not through physical struggles, such as encouraging through national songs, or those who struggle with plunge into the battlefield. I think while my assumption is the same as the assumption of the people that the veterans are those who directly fight against the invaders physically, while the spirit through the songs can also be called a hero just not directly called a veteran. (Based on interview result dated May $12,2015)$

After asking about the students 'knowledge related to their knowledge of veterans, the writer also wanted to know the students' opinion about the brave Indonesian people and willing to sacrifice their soul and body to fight for Indonesian independence.

According to grade IX students who initials SA said: "It is good that I think those who are willing to sacrifice their soul and body for the independence of Indonesia but I think Indonesia is not yet completely free from invaders, because there are still many Indonesian people who use products abroad and even they are more proud to use products abroad than domestic products, in addition to the sea and islands in Indonesia is still threatened by other countries who want to master it. Therefore, to overcome mental colonization, it is necessary to instill Pancasila in self that is implanted in our daily life ". (Based on the results of May 11, 2015).

Another opinion that is not much different is raised by the students of class IX with the initials A states that: "Good, because they are strong enough to defend Indonesia from the invaders at the expense of their body and soul but I think we have not completely free from colonialism because we are still colonized mentally and to overcome it is necessary to study diligently, obediently and not to argue with parents and teachers ". (Based on the results of May 11, 2015). 
Meanwhile, according to students of class IX with initials QA states that: "Dare to seize the independence it already has a soul like a hero can already give up the soul and body means it is good, but Indonesia is not yet fully independent, because the people of Indonesia still do not feel independent mentally and the way to overcome them is to study hard, be cautious to God, and by instilling that Indonesia must be maintained ". (Based on the results of May 11, 2015).

Another opinion was also expressed by the eighth grader of the class VIII, NJ: "I am proud of those who are willing to sacrifice their soul and body for the independence of Indonesia, hopefully it can continue and grow as well, but I think Indonesia has not been completely apart from colonialism, there are still many children of the nation who fall into the cultures from outside and to overcome this by way of continuing to learn and boast Indonesia as well. " (Based on the results of interview dated May 12, 2015).

A similar opinion was also expressed by a Class VIII student with the initials IR stated that: "It is worth rewarding because they have been willing to sacrifice their property, soul, family and also their children should they be rewarded. And I think that Indonesia is not yet fully independent because of globalization for example the existence of the internet with the sites that should not be watched by small children, but the children already have laptops and also mobile phones so they are easy to access these sites because it is to overcome these things that I will definitely try not to join in with negative things like away from drugs, liquor and others. Then I will invite people around me as well so as not to follow-along and fall into things like that ". (Based on the results of May 11, 2015).

$\mathrm{MD}$, who is also a grade VIII student, expressed his opinion that: "Their sacrifices must be respected and respected because they are willing to sacrifice for the state at the expense of their soul and body and I think maybe if the physical colonization is already free, but now there are still many problems such as colonialism from within with the existence of drugs so to overcome it then the effort that I can do is to be smart in choosing the association ". (Based on the results of May 11, 2015).

While the students of grade VII with initials MI also expressed his opinion that: "I think it is very good, the Indonesian nation we have to take good care and we must also preserve not taken colonists, so in my opinion to sacrifice body and soul for the people of Indonesia a good attitude and I think that the physical colonization of our war is free at this time but if the small colonists still have not and my efforts to overcome it is one of them using domestic products, study and preserve Indonesian culture and not follow the culture outside. (Based on the results of May 11,2015).

Students with the initials RF who is also a student of class VII expressed his opinion that: "Very good, because they are willing to sacrifice their soul and body for their descendants of the nation's children in the future but I think at this time we are not completely free from colonization because one of them is still many Indonesians who work abroad as migrant workers and migrant workers who some of them are tortured and suffer there, and my attempt to overcome mental colonization is to fortify myself with faith and piety and continue to study hard. " (Based on the results of May 11, 2015).

Another opinion is also expressed by the students of class VII with initials YS states that: "Good, they really defend Indonesia is its own country at the expense of their body and soul but I think at this time we have not completely free from colonialism, because there are still many Indonesian children who are more interested in outside cultures than our own, and what we have to do is we must learn about Indonesian culture we must preserve it by telling our other friends and we also learn about other tribal cultures. " (Based on the results of May 11, 2015).

The independence of Indonesia that has been achieved by our nation has a long process and the characters who fight for it. Therefore, the authors want to know the opinions of students about the struggle and process in gaining that independence. A class IX student with the initials SA stated that: "The independence we gained in my opinion is Japanese giving, that we are assisted by the same promise of Japan, and for the long process of independence of the RI that I know of Sukarno kidnapped on Rengasdengklok event". (Based on interview result on May 11, 2015).

Another opinion expressed by the students of class IX with the initials "A" states: "The independence we gain in my opinion is not a gift from a foreign nation, because Indonesia is fighting for the nation and its own country, if the struggle for independence I do not know. (Based on interview result on May 11, 2015).

A similar opinion was raised by a class IX student whose initials QA states that: "The independence we gain is not a gift from a foreign nation, because the Indonesian fighters themselves are taking it and fighting for Indonesia. And the process of the struggle in the first outline the foreign countries came up with a good goal to give independence to provide protection from other nations but instead they want to attack and seize the wealth in Indonesia and the people and the fighters in Indonesia they eventually strike back until finally the people of Indonesia can achieve independence ". (Based on interview result on May 11, 2015).

While students of class VIII with initials NJ also expressed the opinion states: "The independence we get is not given by a foreign nation, this is the gift of Indonesia and from the hands of Indonesia itself and we have sacrificed many heroes who died and died we should respect while the process if not mistaken it's Ir. Soekarno wanted to declare independence before that Ir. Sukarno was taken to Rengasdengklok to be exiled by the youths who wanted and encouraged Sukarno to quickly declare the independence declaration accompanied by Moh. Hatta, Ir. Soekarno declared the proclamation and it was also the encouragement of the youths ". (Based on interview result dated May 12, 2015).

Opinions that are not much different is raised by the IR of class VIII students who stated: "The independence we obtain is not a gift from a foreign nation, because we are fighting for ourselves because foreigners never give us anything, the people of Indonesia against the invaders at the expense of many things, then they were forced to work, forcibly planted with 
results they did not fully acquire and then they were tortured and forced to perform various occupations by the occupiers by being slaves and finally because of the feeling of their destiny and endurance that they finally united to achieve the independence we feel today " . (Based on interview result on May 11, 2015).

A similar opinion was also expressed by a student of class VIII with the initials MD stated: "Our independence is not a gift from a foreign nation, because Japan had promised independence for Indonesia but Japan did not keep that promise, but we ourselves are struggling to achieve that independence, and for the process of struggle that our nation passes from the beginning we are colonized by various nations like the Netherlands, Japan and finally arrived at the Rengasdengklok incident until the events of 17 August 1945 ". (Based on the results of interview on May 11, 2015)

While MI grade VII students expressed his opinion that: "We are never given independence by foreign nations, our independence today is the result of hard work and sweat from our own hero to fight for the nation of Indonesia and as I remember the last time when grade VI SD Indonesia originally colonized by the Portuguese, English, Dutch and then afterwards Japan promised independence to Indonesia to help Japan against the Allies, then afterwards on the efforts of the people of Indonesia itself eventually Indonesia's independence ". (Based on interview result on May 11, 2015).

Opinions that are not much different is also expressed by students of class VII with initials RF states: "Foreign nation does not give us independence, because our independence is the result of sweat of our fighters, if the stages or process of struggle of the Indonesian nation to achieve independence I do not memorize ". (Based on interview result on May 11, 2015).

A similar opinion is also expressed by YS class VII students who stated that: "We are not granted independence by foreign nations or other countries, the independence we gain because of the thoughts, strengths and unity of the Indonesian people themselves, the Indonesian nation is colonized by colonists because the colonists want to master the spices in Indonesia and finally because of the colonialism experienced by the Indonesian people that bring the consequences of prolonged suffering so that they want to be free from colonizers and independence until they finally fight against the invaders at the expense of their property, soul and body until Indonesia is independent August 17, 1945 ". (Based on interview result on May 11, 2015).

The history of the Indonesian struggle in seizing and maintaining independence has valuable values as role model and role model for the young generation in the life of society, nation and state. So the author wants to know about the meaning of the values of the struggle of independence fighters, especially veterans against students.

According to grade IX students who initials SA said that: "The values of the struggle that I get for example at the flag ceremony every Monday feels that the first hot-fought struggle but now we feel less how hot than those who fought against the occupiers first. Therefore, as a student needs a sense of patriotism, discipline, patience, never give up in terms of learning and mutual cooperation in the school environment such as cleaning the mosque, clean the place $w h u d u$ and form a learning group. (Based on interview result on May 11, 2015).

Another opinion expressed also by students of class IX with the initials A states: "The values of struggle that I get such as unyielding values such as continuous learning to achieve success, the spirit of struggle that I apply with diligent study, helping people or friends who need help or distress, clean up the school environment with friends and help teachers who need help" (Based on interview result on May 11, 2015).

A class IX student with the initials QA expressed his opinion that: "Must appreciate the services of the heroes who have competed for independence by studying hard and do not despair continue to struggle against the ugliness that exist in Indonesia by trying to become an orderly and obedient student, work together in cleaning the environment around the school and by studying the histories of the heroes who have fought, with respect for his services and by following the flag ceremony, as there is a sense of pride towards Indonesia is now free, with the struggle of the hero first feeling happy (Based on interview result on May 11, 2015).

Another opinion was also expressed by the eighth grader who initials NJ states: "The spirit of unity, sacrifice, love of the homeland, discipline, and also proud, follow the learning and teaching activities well, then instill the value in the self-first so as to grow the sense of love homeland and certainly every Monday following the ceremony and it feels tense and touching, as there is a spirit to continue to learn and learn and never give up the example of pursuing dreams and ideals without despair, learning without never giving up though difficult but must still be implemented and clean- clean, participate in school organizations to clean up the school environment, and group work with friends ". (Based on interview result May 12, 2015).

IR who is also a grade VIII student expressed his opinion stated that: "The value of the struggle that I got first is that we should respect our own country because it is not easy to get the country, the second we must respect the heroes because otherwise they are impossible we can be like this and the third is proud to be an Indonesian citizen, study diligently, respecting teachers and friends and instilling religious values in ourselves ". (Based on interview result on May 11, 2015).

Opinions that are not much different is expressed also by students with initials MD who is also a student of class VIII states: "The value of the struggle to sacrifice for the sake of the state, always do best, learn about the hero, when following the ceremony at a moment of silence follow with and if honestly actually tired of attending the ceremony, but in the ceremony itself there are values such as in the moment of silence, when singing national songs like there is feeling tired and proud of it as well as the value of abstinence I also planted in me as in the field of if sport, for example, in basketball I happen to be basketball team leader even though we lost we will not give up and if we lose we will be more active practice continuously, and also gotong royong for example cleaning class and also for example not schedule picket we still help, other than that group work together friend". (Based on interview result on May 11, 2015). 
While the students of grade VII with initials MI expressed his opinion also stated: "The value of the struggle that I get is hard work, never give up for example when I follow the race volley and lose and I do not give up to come and finally I succeed by always practicing with enterprising, in school when I get low grades so I do not give up in learning and I keep studying diligently to try well besides picketing with classmates and clearing the school areas and defending the right and besides also keeping in mind the services of the heroes. "(Based on interview results dated May 11, 2015).

Opinions other also delivered by students of class VII with initials RF that states that: "The value of the struggle that I get such unyielding for example when I get a bad score I will continue to learn so that I can get good grades and always persistent in the face of trials and obstacles and by continuing to learn, and responsible in doing schoolwork, following the flag ceremony with solemnity and joy and also cleaning the classroom and cleaning up the environment around the classroom with friends ". (Based on interview result May 11, 2015).

According to YS class VII students stated that: "I think the values of the struggle that I get that we must maintain unity and unity, the responsibility we guard in the Indonesian nation by the way we have to study hard, study diligently, love with parents and teachers as well as defend the nation besides following the flag ceremony every Monday although tired but there are values contained in it that is the value of struggle, never give up for example when the test gets ugly then we to get good grades then we must study hard again by not abstinence in learning and every Jum'at gotong royong clean up the school rubbish, picket with class clean up with friends ". (Based on interview result of May 11, 2015)

Based on the perception of some students and teachers to prove that in the process of achieving, fighting for, defending and defending the independence of Indonesia, the people of Indonesia, especially the freedom fighters of Indonesia to do many struggles worthy to be imitated, the values of struggle that we must model and practice in the life of the community, nation and state.

\section{CONCLUSION}

Based on the results of research and discussion it can be collected that (1) The perception of the students of state junior high school 2 Samarinda about the veteran service of Indonesian independence fighters in fighting for the independence of Indonesia is a hero or fighters in the past who fought to take up arms to seize and maintain the independence of Indonesia and their duties are considered to have ended with the end of the struggle period physically and even now some of them are still alive, (2) The meaning of the values of veteran struggle against students of state junior high school 2 Samarinda is patriotism, unyielding, mutual cooperation, discipline, love of the homeland, and willing to sacrifice that is applied in everyday life both in school environment, society, nation and state with diligent and diligent learning to achieve the ideals, work together to clean the school environment in order to create a harmonious relationship and sense of kinship among others, following the rules and school rules, and participate in commemorations of national holidays such as the day of heroes as a form gratitude and appreciation for the heroes.

Based on the above conclusions it is recommended to teachers and students to: (1). To principals and teachers in addition to organizing activities such as flag raising ceremonies during commemorations of national holidays such as the day of heroes in the school environment, at times also following the commemoration of national holidays such as the day of heroes outside the school. In addition, teachers in schools especially PPKn teachers not only provide knowledge only to students or learners but also provide good examples as exemplary students in school for the next generation of Indonesia, especially students or students to get a decent education to form within the self they are faithful and cautious personality and character. (2) To the students or students as the younger generation and the next generation of the Indonesian nation should keep the association so as not to fall into negative things such as promiscuity and drugs, continue to study hard especially about the history of the struggle of the Indonesian nation and other useful knowledge to be intelligent individuals as well as active students in the classroom as well as in the school environment by being active in school organizations and extracurricular activities of interest, to be good citizens and love their homeland by being outstanding students.

\section{REFERENCES}

[1] Arikunto, Suharsimi, 2010, Prosedur Penelitian Suatu Pendekatan Praktik, Jakarta: Rineka Cipta.

[2] Narbuko, Cholid dan Abu, Achmadi, 2007, Metodologi Penelitian, Jakarta: Bumi Aksara.

[3] Peraturan Pemerintah Republik Indonesia Nomor 67 Tahun 2014 tentang pelaksanaan Undang-Undang Nomor 15 Tahun 2012 tentang Veteran Republik Indonesia.

[4] Peraturan Presiden Republik Indonesia Nomor 79 Tahun 2014 tentang pelaksanaan Undang-Undang Nomor 15 Tahun 2012 tentang Veteran Republik Indonesia.

[5] Sugiyono, 2014, Memahami Penelitan Kualitatif, Bandung: Alfabeta.

[6] Undang-Undang Republik Indonesia Nomor 15 Tahun 2012 tentang Veteran Republik Indonesia.

[7] Undang-Undang Republik Indonesia Nomor 20 Tahun 2013 tentang Sistem Pendidikan Nasional.

[8] Walgito, Bimo, 2003, Psikologi Sosial (Suatu Pengantar), Yogyakarta: CV Andi Offset (Penerbit Andi). 